\title{
ANALISIS STRUKTUR RETORIKA DAN PENANDA KEBAHASAAN BAGIAN HASIL DAN PEMBAHASAN ARTIKEL JURNAL PENELITIAN BISA FKIP UNIB UNTUK BIDANG PENGAJARAN BAHASA
}

\author{
Herni Yanita \\ herniyanita@yahoo.co.id \\ Alumni Program pascasarjana Pendidikan Bahasa Indonesia, Universitas Bengkulu
}

\begin{abstract}
Abstrak
This study aimed to describe macro rhetoric structures and linguistic markers in the result and discussion of BISA journal of language pedagogy. This study used descriptive method. The data in this research were linguistic markers in text from Research Articles (RA) entitled research journal article BISA that specifically discuss about language pedagogy. The analysis of rhetoric structure used Swales theory consisting of 8 moves. Meanwhile, linguistic markers were defined as text genre regarding to active and passive sentence and cohession markers. The analysis result of rhetoric structures from result and discussion session in research journal article BISA research articles were the movements that were used in the rhetoric structure of research journal article BISA Journal which were move 1 with (information about the research), move 2 (statement about the result of research), move 5 (explanation about the result of the research). On the other side, for the linguistic markers found in the result and discussion section of research journal articles BISA journal were: linguistic markers in all movements (1) active sentence and passive sentence (2) cohession markers.
\end{abstract}

Kata Kunci: Rhetoric structure, linguistic markers, Research Journal Articles.

\section{PENDAHULUAN}

Artikel adalah salah satu karya ilmiah yang ditulis berdasarkan hasil penelitian dan hasil pemikiran atau kajian pustaka. Artikel jurnal penelitian BISA merupakan jurnal khusus yang dikelola oleh program pascasarjana pendidikan bahasa Indonesia FKIP UNIB yang mempublikasikan hasil penelitian mahasiswa program pascasarjana (S2) PBI UNIB. Artikel jurnal penelitian ini memiliki struktur penulisan berupa abstrak, pendahuluan, metodologi penelitian, pembahasan, kesimpulan dan daftar pustaka. Bagian hasil dan pembahasan dalam artikel jurnal penelitian adalah bagian yang paling penting, pada bagian hasil dan pembahasan peneliti melaporkan hasil laporan yang diteliti. Penulis harus juga menjelaskan mengapa hasil penelitian mereka seperti yang ditemukan dan apa maksudnya. Pada bagian pembahasan peneliti juga harus meringkas dan menafsirkan hasil penelitian mereka dan mengomentari setiap poin yang diajukan dalam pertanyaan atau hipotesis penelitian seperti yang dikemukakan Thyer dan Branson (dalam Safnil 2014:161). Menurut Swales (dalam Safnil 2014 : 162) bahwa bagian pembahasan artikel jurnal penelitian dapat memiliki delapan tahapan (moves) atau segmen teks yang memiliki tujuan komunikatif yang jelas untuk pembaca. Namun dari delapan tahapan tersebut tidak semua digunakan dalam bagian hasil dan pembahasan. Sejalan dengan teori ini 
Adnan dan Firdaus (dalam Santoso,2014: 87-89) juga menyebutkan tahapantahapan dalam sebuah pembahasan karya ilmiah yang terdiri dari 7 tahapan.

Dalam sebuah artikel penelitian penanda kebahasaan juga menjadi sebuah hal yang harus diperhatikan oleh penulis artikel penelitian. Salah satu komponen dari penanda kebahasaan yakni kalimat yang merupakan sarana komunikasi khususnya komunikasi tertulis untuk menuangkan pikiran maupun gagasan kepada pembaca supaya dapat dipahami dengan baik. Penanda kebahasaan adalah sebuah alat untuk memahami apa yang menjadi gagasan secara jelas dan nyata serta tidak menimbulkan kebimbangan pembaca (Safnil dan Wardana, 2013: 5). Berdasarkan uraian diatas peneliti tertarik untuk mengadakan penelitian bagaimana struktur retorika dan penanda kebahasaan bagian hasil dan pembahasan artikel jurnal penelitian BISA bidang pengajaran bahasa.

\section{METODE PENELITIAN}

Metode yang digunakan dalam penelitian ini ialah menggunakan metode penelitian deskriptif dengan pendekatan kuantitatif sederhana. Menurut Best (dalam Sukardi, 2009: 157) menjelaskan metode deskriptif merupakan metode penelitan yang berusaha menggambarkan dan menginterpretasikan objek sesuai dengan apa adanya. Arikunto (2010:3) menegaskan bahwa metode diskriptif yaitu penelitian yang dimaksudkan untuk menyelidiki keadaan, kondisi, dan hal-hal lain. Ratna (2012:53) menegaskan bahwa penelitian deskriptif analitik dilakukan dengan cara mendeskripsikan fakta-fakta yang kemudian disusul dengan analisis. Metode penelitian ini digunakan untuk mendeskripsikan struktur retorika pada teks bagian hasil dan pembahasan artikel jurnal penelitian BISA bidang pengajaran bahasa.

\section{HASIL DAN PEMBAHASAN}

Struktur retorika dan penanda kebahasaan menjadi hal yang menarik untuk dibahas. Berdasarkan teori Swales dalam Safnil yang menjelaskan bahwa tahapan- tahapan yang terdapat dalam bagian hasil dan pembahasan AJP itu ada 8 tahapan. Dari 8 tahapan yang diteliti, tahapan yang paling dominan digunakan dalam AJP BISA Bidang Pengajaran Bahasa adalah tahapan 5 (Penjelasan tentang hasil penelitian), Tahapan 2 (Pernyataan tentang hasil penelitian), Tahapan 6 (llustrasi untuk mendukung hasil penelitian) serta tahapan 1(Informasi tentang penelitian).Namun, pada 50 AJP BISA Bidang Pengajaran Bahasa yang diteliti ada tahapan yang jarang sekali ditemukan dalam AJP tersebut yaitu tahapan3 (Pernyataan tentang hasil penelitian yang tidak terduga ), Tahapan 4 (Penggunaan referensi dari penelitian sebelumnya), tahapan 7 (Penafsiran peneliti terhadap hasil penelitian) serta tahapan 8 (Saran peneliti sebagai implementasi praktis dari temuan penelitian). Selain Swales, temuan penelitian ini sejalan dengan temuan penelitian Safnil dan Wardana (2014).

Kemudian Santoso (2014: 89) juga mnegungkapkan tidak semua tahapan tersebut terdapat pada sebuah pembahasan karya ilmiah. Kadang kala pembahasan diawali dengan menampilkan ringkasan temuan penelitian dan juga tidak semua pembahasan 
mengandung rekomendasi untyuk penelitian selanjutnya.

Peneliti juga meneliti penanda kebahasaan dalam Artikel Jurnal Penelitian BISA Bidang Pengajaran Bahasa. Berdasarkan hasil analisis dapat disimpulkan bahwa di dalam AJP BISA Bidang Pengajaran Bahasa terdapat penanda kebahasaan yang berupa kalimat aktif dan kalimat pasif serta penanda kohesi. Penanda kebahasaan tidak terlepas dari kalimat dan paragraf, dimana kalimat dan paragraf termasuk dalam ilmu bahasa baik lisan maupun tulisan.Kalimat merupakan sarana komunikasi untuk menyampaikan pikiran atau gagasan kepada orang lain agar dapat dipahami dengan mudah. Untuk itu, kalimat harus disusun berdasarkan struktur yang benar, pengungkapan gagasan secara baik, singkat, tepat, jelas, maknanya, dan santun.

Kalimat aktif maupun pasif ini mampu mempengaruhi keefektifan dalam kalimat atau wacana.Kalimat yang benar dan jelas dengan mudah dipahami orang lain secara tepat. Keefektifan sebuah kalimat menjadi persoalan bagaimana sebuah kalimat dapat secara tepat mewakili isi pikiran atau perasaan seseorang, dan bagaimana kalimat itu dapat disajikan secara segar, hidup, dan sanggup menarik perhatian pembaca atau pendengar terhadap apa yang dibicarakan. Hal ini berarti kalimat efektif harus disusun secara sadar untuk mencapai daya informasi yang diinginkan penggagas terhadap pembacanya. Safnil (2014:65) mengungkapkan dalam penelitiannya bahwa kalimat pasif digunakan untuk menarik kesimpulan dan hasil penelitian. Kalimat aktif digunakan untuk membahas hasil atau mengajukan saran.
Penanda kohesi yang dominan digunakan dalam AJP BISA bidang pengajaran bahasa adalah penanda kohesi gramatikal yang terdiri dari pronomina yakni kata ganti orang dan kata ganti penunjuk, serta penggunaan konjungsi yang paling dominan digunakan dalam AJP BISA bidang pengajaran bahasa adalah konjungsi koordinatif dan konjungsi subordinatif. Berdasarkan hasil analisis data tentang penggunaan penanda kebahasaan yang berupa konjungsi dalam AJP BISA Bidang Pengajaran Bahasa dapat disimpulkan bahwa penggunaan konjungsi koordinatif seperti kata dan, atau, tetapi, namun pada konjungsi lainnya hampir ditemui pada seluruh AJP BISA Bidang Pengajaran Bahasa. Selain itu, Penggunaan subordinatif atribut yaitu kata yang juga hampir ditemukan dalam seluruh AJP BISA Bidang Pengajaran Bahasa. Sedangkan penanda kohesi leksikal yang digunakan dalam AJP BISA ini adalah penanda kohesi leksikal repetisi atau pengulangan kata yang sama.

\section{SIMPULAN}

Adapun kesimpulan dari hasil penelitian dan pembahasan mengenai struktur retorika dan penanda kebahasaan bagian hasil dan pembahasan AJP BISA Bidang Pengajaran Bahasa sebagai berikut :

1. Struktur retorika bagian hasil dan pembahasan yang dominan muncul dalam bagian hasil dan pembahasan AJP BISA bidang pengajaran bahasa terdiri dari empat tahapan yakni : (1) informasi tentang penelitian, (2) Pernyataan tentang hasil penelitian, (5) Penjelasan tentang hasil penelitian, (6) Ilustrasi untuk mendukung penjelasan hasil penelitian. Adapun tahap 3 (pernyataan 
tentang hasil penelitian yang tak terduga), tahapan 4 atau(penggunaan referensi dari penelitian sebelumnya),tahap 7(Penafsiran peneliti sebagai implementasi dari temuan penelitian) serta tahap 8(saran peneliti sebagai implementasi dari temuan penelitian)sangat jarang digunakan dalam bagian hasil dan pembahasan Artikel Jurnal Penelitian BISA Bidang Pengajaran Bahasa.

2. Sedangkan penanda kebahasaan yang terdapat dalam bagian hasil dan pembahasan AJP BISA bidang pengajaran bahasa antara lain : kalimat aktif lebih dominan digunkan dibandingkan kalimat pasif. Penanda kohesi gramatikal yang terdiri dari pronomina yakni kata ganti orang dan kata ganti penunjuk serta penggunaan konjungsi yang paling dominan digunakan dalam AJP BISA bidang pengajaran bahasa adalah konjungsi koordinatif dan subordinatif sedangkan penanda kohesi leksikal yang digunakan dalam AJP BISA bidang pengajaran bahasa adalah repetisi atau pengulangan kata yang sama.

\section{Daftar Pustaka}

Arikunto, Suharsimi. 2010. Penelitian Kualitatif. Jakarta: Bumi Aksara.

Astuti, Wiwiek Dwi. 1999. Bahasa dan Sastra Ihwal Perbedaan Kohesi Penyulihan dan Pengacuan dalam Wacana Bahasa Indonesia. Jakarta: Pusat Pembinaan dan Pengembangan Bahasa Departemen Pendidikan dan Kebudayaan.

Bungin, Burhan. 2008. Penelitian Kualitatif; Komunikasi, Ekonomi, Kebijakan Publik, IImu Sosial
Lainnya. Jakarta: Kencana Prenada Media Group.

Chaer, Abdul. 2007. Kajian Bahasa Struktur Internal, Pemakaian, dan Pembelajaran. Jakarta: Rineka Cipta.

Chaer,Abdul.2007.Gramatika Bahasa Indonesia.Jakarta: Rineka Cipta.

Dalman. 2014. Menulis Karya Ilmiah. Jakarta: PT.Raja Grafindo Persada.

Darma, Aliah Yoce. 2009. Analisis Wacana Kritis. Bandung: Yrama Widya.

Djajasudarma, Fatimah T. 2012. Wacana dan Pragmatik. Bandung: Refika Aditama.

Hayon, Josep. 2003. Membaca dan Menulis Wacana. Jakarta: Storia Grafika.

HP, Achmad. 2010. Paradigma dan Pendekatan Analisis Wacana. Jakarta: Program Pascasarjana Universitas Negeri Jakarta.

HS, Widjono. 2011. Bahasa Indonesia Mata Kuliah Pengembangan Kepribadian di Perguruan Tinggi. Jakarta: Grasindo.

Ihsan, Diemroh. 2011. Pragmatik, Analisis Wacana, dan Guru Bahasa. Palembang: Universitas Sriwijaya.

Keraf, Gorys. 1994. Diksi dan Gaya Bahasa. Jakarta: Gramedia Pustaka Utama. 
2010. Komposisi. Jakarta: Nusa Indah.

Lubis, Hamid Hasan. 1991. Analisis Wacana Pragmatik. Bandung: Angkasa.

Moleong, Lexy J. 1988. Metode Penelitian Kualitatif. Bandung: Remaja Rosdakarya.

Muhtadin. 2014." Analisis struktur retorika dan fitur linguistik bagian pendahuluan artikel jurnal penelitian berbahasa Indonesia dalam bidang ilmu hukum." Tesis: Universitas Bengkulu.

Mulyana. 2005. Kajian Wacana. Yogyakarta: Tiara Wacana.

Mulyono,lyo.2012.Ikhwal Kalimat dalam Bahasa Indonesia dan Problematik

Penggunaannya.Bandung: Yrama Widya.

Murfauziah. 2014." Analisis struktur retorika dan fitur linguistik bagian pendahuluan artikel jurnal penelitian berbahasa Indonesia dalam bidang ilmu sosial dan humaniora." Tesis: Universitas Bengkulu.

Murti, Sri. 2014. "Analisis struktur retorika dan fitur linguistik bagian pendahuluan artikel jurnal penelitian berbahasa Indonesia dalam bidang ilmu linguistik." Tesis. Universitas Bengkulu.

Nainggolan,Juliana.2015." Pengembanga $n$ Model struktur Retorika PJP Pada Teks Bagian Pendahuluan
AJP BISA yang Bersifat Deskriptif." Tesis : Universitas Bengkulu.

Nurgiyantoro, Burhan. 2010. Teori Pengkajian Fiksi. Yogyakarta: Gajah Mada University Press.

Oka,I Gusti Ngurah. 1976. Retorika Sebuah Tinjauan Pengantar. Bandung: Tarate.

Pateda, Mansoer. 2010. Semantik Leksikal. Jakarta: Rineka Cipta.

Ratna, Nyoman Kutha. 2012. Teori, Metode, dan Teknik Penelitian Sastra.Yogyakarta: Pustaka Pelajar.

Safnil. 2010. Pengantar Analisis Retorika Teks. Bengkulu: FKIP UNIB Press.

2013. 'A Genre-Based Analysis on the Introduction of Research ArticlesWriten by Indonesian Academics' dalam TEFLIN Jurnal, Vol.24, No.2, pp: 180-200.

. dan Dian Eka Chandra Wardhana. 2013. Analisis Struktur Retorika dan Fitur Linguistik Teks Bagian Pendahuluan Artikel Jurnal Penelitian Berbahasa Indonesia Dalam Berbagai Bidang IImu. Bengkulu: Usulan Penelitian Tim Pascasarjana Universitas Bengkulu.

2014.Menulis Artikel Jurnal
Internasional Dengan Gaya
Retorika Bahasa Inggris.
Bengkulu: FKIP Unib Press.

Santoso, Urip. 2014. Kiat Menulis Artikel Ilmiah. Yogyakarta: Graha IImu.

Subakti, Agung. 2014." Analisis struktur retorika dan fitur linguistik 
bagian pendahuluan artikel jurnal penelitian berbahasa Indonesia dalam bidang ilmu Isastra."Tesis Tidak Diterbitkan. Bengkulu: Universitas Bengkulu.

Sudaryat,Yayat. 2008. Makna dalam Wacana. Bandung: Yrama Widya.

Suhandang, Kustadi. 2008. Retorika Strategi Teknik dan Taktik Pidato. Bandung: Nuansa.

Sudjana, Nana. 1991. Tuntunan Penyusunan Karya Ilmiah. Bandung: Sinar Baru.

Sukardi, 2009. Metodologi Penelitian Pendidikan. Jakarta: Bumi Aksara.

Susetyo, 2009. Menulis Akademik. Bengkulu: FKIP UNIB.

Tarigan.1984. Pengajaran Sintaksis. Bandung : Angkasa.
Tjiptadi, Bambang dan Negoro, ST. 1985. Tata Bahasa Indonesia. Semarang: Yudhistira.

Wahab,Abdul. 1991. Isu Linguistik Pengajaran Bahasa dan Sastra. Surabaya: Airlangga University Press.

Wardhana,Dian Eka Chandra. 2016. Konstruksi Retorika yang Terefleksikan dalam Proses Kreatif Penulisan Bab temuan Penelitian dan Pembahasan AJP Berbahasa Indonesia di Jurnal Akreditasi Bidang Penelitian Bahasa;Kolita 14,HIm 194-195)

Widjono. 2011. Bahasa Indonesia ( Mata Kuliah Pengembangan Kepribadian di Perguruan Tinggi). Jakarta : Grasindo.

Zaimar, Okke Kusuma Sumantri dan Ayu Basoeki Harahap. 2011. Telaah Wacana Teori dan Penerapannya. Depok: Komodo Boks. 